\title{
Structure and Magnetic Properties of Quasi-One Dimensional Cobalt-Doped Scandium Cuprate Compounds
}

\author{
Nobuhito IMANAKA, Toshihiro SHIMIZU, Fumihiko SAITO, Yasuyuki KOBAYASHI, \\ Gin-ya ADACHI, Guo LIU* and John Edward GREEDAN* \\ Department of Applied Chemistry, Faculty of Engineering, Osaka University, 2-1, Yamadaoka, Suita-shi, Osaka 565 \\ *Institute for Materials Research, McMaster University, 1280, Main Street West, Hamilton, Ontario L8S 4M1, Canada
}

\section{コバルトを添加した，擬一次元的配列を持つスカンジウム銅化合物の構造と磁気的性質 \\ 今中信人 · 清水敏宏 · 斎藤文彦 - 小林靖之 · 足立吟也 - Guo Liu - John Edward Greedan \\ 大阪大学工学部応用化学科, 565 吹田市山田丘 2-1 \\ *Institute for Materials Research, McMaster University, 1280, Main Street West, Hamilton, Ontario L8S 4M1, Canada}

[Received November 2, 1994; Accepted January 19, 1995]

\begin{abstract}
Structure and magnetic properties of the $\mathrm{Sc}_{2} \mathrm{Cu}_{2-x}$ $\mathrm{Co}_{x} \mathrm{O}_{5}$ system were investigated up to the solid solution limits $x=0.4$ and $x=0.6$. Undoped $\mathrm{Sc}_{2} \mathrm{Cu}_{2} \mathrm{O}_{5}$ has, like isostructural $\mathrm{Y}_{2} \mathrm{Cu}_{2} \mathrm{O}_{5}$, a magnetic structure with weak ferromagnetic coupling along the $b$-axis and strongly coupled $\mathrm{Cu}^{2+}$ chains parallel to the $a$-axis which were antiferromagnetically coupled below the Néel temperature of $16 \mathrm{~K}$. Doping with $\mathrm{Co}^{2+}$ caused the paramagnetic Curie temperature $\left(\theta_{\mathrm{p}}\right)$ to decrease from the $x=0$ value of $40 \mathrm{~K}$, making $\left(\theta_{\mathrm{p}}\right)$ negative for $x>0.2$, and caused the Néel temperature to increase to about $35 \mathrm{~K}$ for $x=0.4$. Thus the interchain weak ferromagnetic coupling along the $b$-axis was weakened and the interchain antiferromagnetic coupling was strengthened, while the intrachain strong ferromagnetic coupling, which displays the one-dimensional spin-spin interaction, was not influenced by the Co doping. Room-temperature structure refinement for $\mathrm{Sc}_{2} \mathrm{Cu}_{1.6} \mathrm{Co}_{0.4} \mathrm{O}_{5}$ from neutron powder diffraction data indicated that random substitution of $\mathrm{Co}^{2+}$ for $\mathrm{Cu}^{2+}$ occurred and that the $\mathrm{Cu}-\mathrm{O}-\mathrm{O}-\mathrm{Cu}$ interchain superexchange pathway was enhanced by geometric changes as $x$ increased from $x=0$ to 0.4 .
\end{abstract}

Key-words : Cuprate, Scandium, Ferromagnetism, Antiferromagnetism, Superexchange, Néel temperature, Spinspin interaction

\section{Introduction}

Rare earths such as $\mathrm{Tb}-\mathrm{Lu}, \mathrm{Y}$ and Sc, have been found to form the oxide $\mathrm{Ln}_{2} \mathrm{Cu}_{2} \mathrm{O}_{5}(225)$ ( $\mathrm{Ln}=$ rare earths), which is isostructural with $\mathrm{Ho}_{2} \mathrm{Cu}_{2} \mathrm{O}_{5} \cdot{ }^{1,2)}$ Among this $\mathrm{Ln}_{2} \mathrm{Cu}_{2} \mathrm{O}_{5}$ series, the magnetic properties of $\mathrm{Y}_{2} \mathrm{Cu}_{2} \mathrm{O}_{5}$ have been investigated in detail, ${ }^{3)-11)}$ -since the $\mathrm{Y}_{2} \mathrm{Cu}_{2} \mathrm{O}_{5}$ phase was found as one of the contaminant in the preparation of the $\mathrm{YBa}_{2} \mathrm{Cu}_{3} \mathrm{O}_{7-\delta}$ (123) superconductor. In addition, the 123 oxide itself shows antiferromagnetic order for $\delta>0.6 .{ }^{12}$ ) Cuprate compounds containing rare earths have received considerable attention due to their interesting magnetic properties as well as their superconducting characteristics.
In the $\mathrm{Ln}_{2} \mathrm{Cu}_{2} \mathrm{O}_{5}$ structure, $\mathrm{Cu}$ and $\mathrm{O}$ form chains of square planer units which alternatively share corners and edges parallel to the $a$-axis, ${ }^{4)}$ and $\mathrm{Cu}^{2+}$ in these chains strongly orders ferromagnetically and causes the one-dimensional magnetic characteristics. Another weak ferromagnetic coupling also exists along the $b$-axis in the 225 compounds. The $\mathrm{Y}_{2} \mathrm{Cu}_{2} \mathrm{O}_{5}$ phase shows an antiferromagnetic-paramagnetic transition at around $13 \mathrm{~K}$. Below the Néel temperature $\left(T_{\mathrm{N}}\right)$, antiferromagnetic ordering appears in the $c$-axis direction. A scandium ion, whose ionic radius is the smallest among the rare earths, also retains the same $\mathrm{Ho}_{2} \mathrm{Cu}_{2} \mathrm{O}_{5}$ structure. Since the ionic radius of $\mathrm{Sc}$ is smaller than that of $\mathrm{Y}$, the interchain coupling is strengthened. This causes the enhancement of the Neel temperature ( $T_{\mathrm{N}}$ values for $\mathrm{Sc}_{2} \mathrm{Cu}_{2} \mathrm{O}_{5}$ and $\mathrm{Y}_{2} \mathrm{Cu}_{2} \mathrm{O}_{5}$ are $16 \mathrm{~K}^{4)}$ and $13 \mathrm{~K}$, ${ }^{5)}$ respectively). For the purpose of obtaining distinct characteristics of magnetic behavior through the intra- and interchain coupling of $\mathrm{Cu}-\mathrm{O}$ chains in the 225 compounds, $\mathrm{Sc}_{2} \mathrm{Cu}_{2} \mathrm{O}_{5}$ is the most appropriate candidate for investigation in the $\mathrm{Ln}_{2} \mathrm{Cu}_{2} \mathrm{O}_{5}$ series. Some magnetic properties $\left.\left.{ }^{4)}, 7\right)-10\right), 14$ ) have been elucidated for $\mathrm{Sc}_{2} \mathrm{Cu}_{2} \mathrm{O}_{5}$ in order to clarify the magnetic behavior of pure $\mathrm{Sc}_{2} \mathrm{Cu}_{2} \mathrm{O}_{5}$, in addition to the vibrational spectra and electrical properties, ${ }^{13)}$ and neutron diffraction analyses have also been performed. ${ }^{9), 14)}$

In this study, another magnetic ion, $\mathrm{Co}^{2+}$ (high spin: $0.0885 \mathrm{~nm}$, low spin: $0.079 \mathrm{~nm}),{ }^{15)}$ whose ionic radius is similar to both $\left.\mathrm{Sc}^{3+}(0.0885 \mathrm{~nm}){ }^{15}\right)$ and $\mathrm{Cu}^{2+}(0.087 \mathrm{~nm}),{ }^{15)}$ was doped in $\mathrm{Sc}_{2} \mathrm{Cu}_{2} \mathrm{O}_{5}$ to form a solid solution to investigate the magnetic properties in more detail. The influence of $\mathrm{Co}^{2+}$ incorporation on the 225 structure and magnetic properties was investigated.

\section{Experimental}

Appropriate amounts of $\mathrm{Sc}_{2} \mathrm{O}_{3}$ (purity: 99.9\%), $\mathrm{CuO}$ (purity: 99.99\%), and $\mathrm{CoSO}_{4} \cdot 7 \mathrm{H}_{2} \mathrm{O}$ (reagent grade) were weighed, mixed in an agate mortar and then pelletized. The pellets were heated at $1000^{\circ} \mathrm{C}$ 

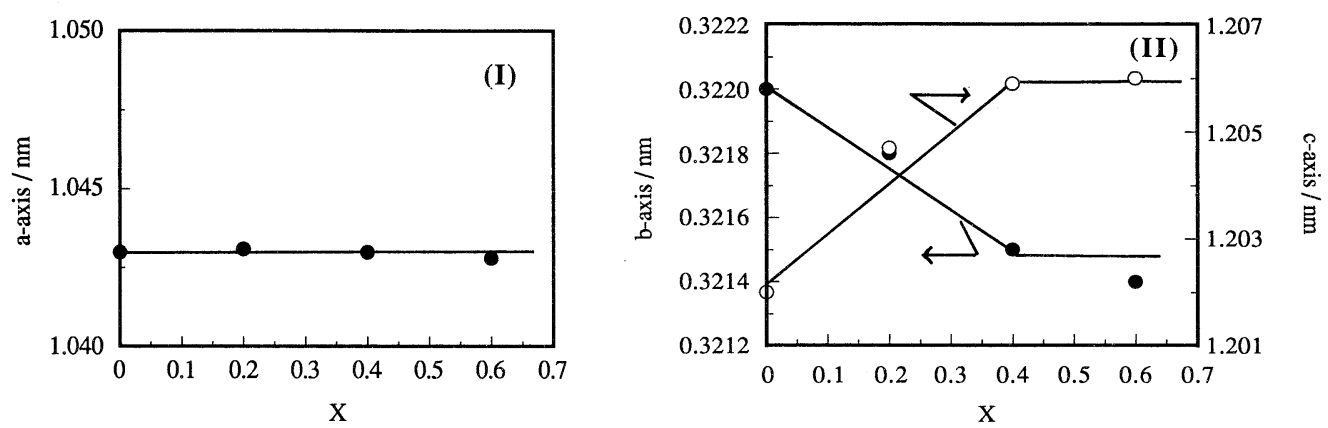

Fig. 1. Variations of the lattice parameter $a$ (I) and the lattice parameters $b$ and $c$ (II) as functions of Co content ( $x$ ) in $\mathrm{Sc}_{2} \mathrm{Cu}_{2-x} \mathrm{Co}_{x} \mathrm{O}_{5}$.

for $6 \mathrm{~h}$ in a flowing oxygen atmosphere and then cooled in the furnace. Since the ionic radius of $\mathrm{Co}^{2+}$ is similar to those of $\mathrm{Sc}^{3+}$ and $\mathrm{Cu}^{2+}$, two types of mixtures were prepared. Type I assumes Co substitution for $\mathrm{Cu}$, i.e., $\mathrm{Sc}_{2} \mathrm{Cu}_{2-x} \mathrm{Co}_{x} \mathrm{O}_{5}$, and Type II assumes $\mathrm{Co}$ substitution for $\mathrm{Sc}$, i.e., $\mathrm{Sc}_{2} \mathrm{Cu}_{x} \mathrm{Co}_{2-x} \mathrm{O}_{5-x / 2}$. $\mathrm{X}$-ray powder diffraction data were obtained using a diffractometer (Rotaflex) from Rigaku Corporation. Lattice parameters were refined using high-resolution Guinier camera data with $\mathrm{Cu} \mathrm{K} \alpha_{1}$, radiation and a $\mathrm{Si}$ standard. Magnetic susceptibility measurements were performed using a torsion magnetic balance from 4.2 to $300 \mathrm{~K}$ at an applied magnetic field of $0.6 \mathrm{~T}$. Neutron diffraction data were obtained by means of the McMaster Nuclear Reactor at McMaster University, Ontario, Canada, using a $0.13913 \mathrm{~nm}$ neutron beam obtained by reflection from a $\mathrm{Cu}(200)$ monochromator. Details of the refinement methods have been described previously. ${ }^{16)}$ Neutron scattering length (fm) used were 12.29, 2.50, 7.718, 5.803 for $\mathrm{Sc}, \mathrm{Co}, \mathrm{Cu}$ and $\mathrm{O}$, respectively. ${ }^{17)}$ The atomic ratio of $\mathrm{Sc}, \mathrm{Cu}$ and $\mathrm{Co}$ was determined by an X-ray fluorescence analyzer, System 3270A from Rigaku Corporation. The oxygen content was measured by an oxygen analyzer, MGA-650 from Horiba Ltd.

\section{Results and discussion}

On the basis of charge considerations, $\mathrm{Co}^{2+}$ is most likely to substitute for $\mathrm{Cu}^{2+}$; however, it is not possible to rule out, a priori, $\mathrm{Co}^{2+}$ substitution for $\mathrm{Sc}^{3+}$. Thus, two solid solution series were investigated initially, namely $\mathrm{Sc}_{2} \mathrm{Cu}_{2-x} \mathrm{Co}_{x} \mathrm{O}_{5}$ (Type I ) and $\mathrm{Sc}_{2-x} \mathrm{Co}_{x} \mathrm{Cu}_{2} \mathrm{O}_{5-x / 2}$ (Type II). A single-phase material, isostructural with $\mathrm{Sc}_{2} \mathrm{Cu}_{2} \mathrm{O}_{5}$, was obtained by Co substitution from $x=0.2$ to up to 0.4 in $\mathrm{Sc}_{2} \mathrm{Cu}_{2-x} \mathrm{Co}_{x} \mathrm{O}_{5}$ (Type I ). For $x=0.6$, a few peaks belonging to $\mathrm{Sc}_{2} \mathrm{O}_{3}$ and $\mathrm{Co}_{3} \mathrm{O}_{4}$ were observed in addition to the peaks identified as belonging to the $\mathrm{Sc}_{2} \mathrm{Cu}_{2} \mathrm{O}_{5}$ structure. In the series of X-ray measurements for the $\mathrm{Sc}-\mathrm{Cu}-\mathrm{Co}-\mathrm{O}$ solid solutions, some peaks corresponding to the $\mathrm{Sc}_{2} \mathrm{Cu}_{2} \mathrm{O}_{5}$ structure monotonically shifted with the increase in Co substitution. On the other hand, in the case of Type II, $\mathrm{CuO}$ was observed in all the samples prepared. $\mathrm{Co}_{3} \mathrm{O}_{4}$ peaks also existed in the samples of $\mathrm{Sc}_{2-x} \mathrm{Co}_{x} \mathrm{Cu}_{2} \mathrm{O}_{5-x / 2}$ from $x=0.2$ to 0.6 . From these results, we can conclude that the Co substitutes not for the Sc site but for the $\mathrm{Cu}$ site and forms a solid solution, up to $x=0.4$ in Type $\mathrm{I}\left(\mathrm{Sc}_{2} \mathrm{Cu}_{2-x} \mathrm{Co}_{x} \mathrm{O}_{5}\right)$. From the X-ray fluorescence and oxygen content analyses, the atomic ratio in the solid solutions was found to be almost the same as that in the nominal composition $\mathrm{Sc}_{2} \mathrm{Cu}_{2-x} \mathrm{Co}_{x} \mathrm{O}_{5}$.

Figures 1(I) and (II) show how the lattice parameters $a, b$ and $c$ axes change with the amount of $\mathrm{Co}$ substitution in $\mathrm{Sc}_{2} \mathrm{Cu}_{2-x} \mathrm{Co}_{x} \mathrm{O}_{5}$. The lattice parameter $c$ monotonically increased up to $x=0.4$. In contrast, lattice parameter $b$ decreased up to the same level of Co substitution. No clear deviation was found in lattice parameter $a$ in the range of compositions studied here. These results indicate that the $\mathrm{Co}$ solubility limit in $\mathrm{Sc}_{2} \mathrm{Cu}_{2-x} \mathrm{Co}_{x} \mathrm{O}_{5}$ is around $x=0.4$.

Figure 2 presents the temperature dependence $(4.2-300 \mathrm{~K})$ of the magnetic susceptibilities of $\mathrm{Sc}_{2} \mathrm{Cu}_{2-x} \mathrm{Co}_{x} \mathrm{O}_{5} \quad(x=0-0.6)$. In order to clarify the difference in the magnetic properties resulting from the Co substitution, $1 / \chi_{m}-T(4.2-300 \mathrm{~K})$ relationships for $\mathrm{Sc}_{2} \mathrm{Cu}_{2} \mathrm{O}_{5}$ (without Co substitution) and $\mathrm{Sc}_{2} \mathrm{Cu}_{1.6} \mathrm{Co}_{0.4} \mathrm{O}_{5}$ (maximum Co substitution) are shown in Fig. 3. $\mathrm{Sc}_{2} \mathrm{Cu}_{2} \mathrm{O}_{5}$ has already been reported to transform from paramagnetic to antiferromagnetic at around $16 \mathrm{~K}$ with decreasing temperature. ${ }^{4)}$ The Néel temperature $\left(T_{\mathrm{N}}\right)$ obtained in our experi-

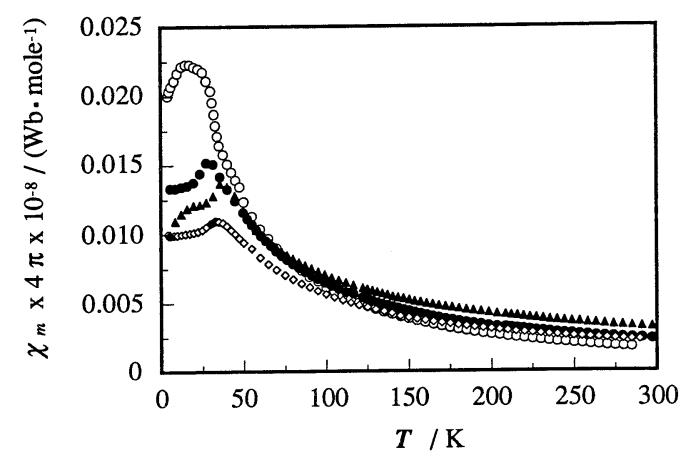

Fig. 2. Temperature dependence of the magnetic susceptibilities of $\mathrm{Sc}_{2} \mathrm{Cu}_{2-x} \mathrm{Co}_{x} \mathrm{O}_{5}(x=0(\bigcirc), x=0.2(\bigcirc), x=0.4(\diamond)$, and $x=0.6(\mathbf{\Lambda}))$. 


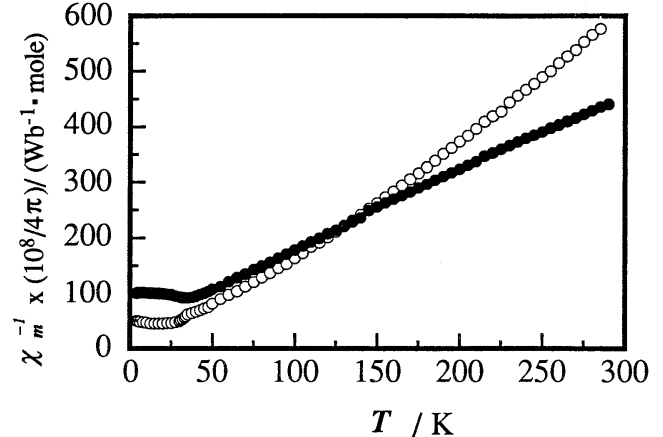

Fig. 3. The $1 / \chi_{m}-T$ relationships for $\mathrm{Sc}_{2} \mathrm{Cu}_{2} \mathrm{O}_{5}(\bigcirc)$ and $\mathrm{Sc}_{2} \mathrm{Cu}_{1.6}$ $\mathrm{Co}_{0.4} \mathrm{O}_{5}(\mathbf{O})$

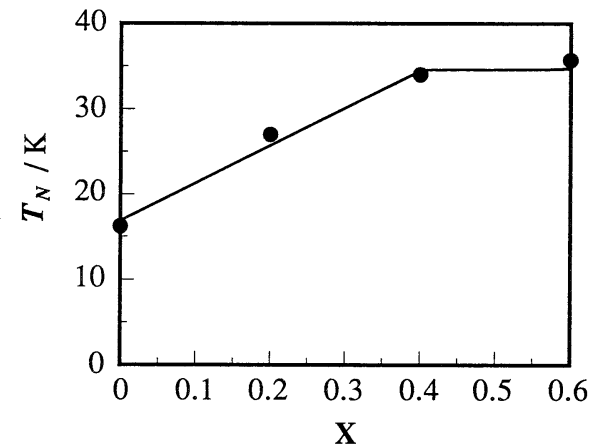

Fig. 4. Relationship between $T_{\mathrm{N}}$ and the amount of Co substitution in $\mathrm{Sc}_{2} \mathrm{Cu}_{2-x} \mathrm{Co}_{x} \mathrm{O}_{5}$.

ment for $\mathrm{Sc}_{2} \mathrm{Cu}_{2} \mathrm{O}_{5}(x=0)$ is almost consistent with this reported temperature. In the temperature region lower than $T_{\mathrm{N}}$, the magnetic susceptibility decreased. This is mainly attributed to the decrease in the magnetic moment, which due to results from random ordering by thermal vibration and reduces the magnetic moment which would be magnetized by the external field. At higher temperatures, the 1/ $\chi_{m}-T$ relationship was almost linear and obeyed the Curie-Weiss law.

Figure 4 presents the relationship between $T_{\mathrm{N}}$ and the amount of Co substitution in $\mathrm{Sc}_{2} \mathrm{Cu}_{2-x} \mathrm{Co}_{x} \mathrm{O}_{5} . T_{\mathrm{N}}$ increased linearly up to $x=0.4$. This is the same behavior as that of the lattice parameter $c$ variation with Co substitution as shown in Fig. 1(II). This increase in $T_{\mathrm{N}}$ occurred as a result of the substitution of $\mathrm{Cu}$ sites by $\mathrm{Co}$ to form a solid solution of $\mathrm{Sc}_{2} \mathrm{Cu}_{2-x} \mathrm{Co}_{x} \mathrm{O}_{5}$.

Figure 5 shows the $\mathrm{Ho}_{2} \mathrm{Cu}_{2} \mathrm{O}_{5}$-type structure in the $a c$ plane, which has been already reported. ${ }^{9)} \oplus$ and $\ominus$ indicate the spins of $\mathrm{Cu}$ ions when $\mathrm{Cu}$ between the chains (along the $c$-axis) orders antiferromagnetically. $\mathrm{Cu}^{2+}$ is wellknown to form a square planar coordination. However, in the case of $\mathrm{Sc}_{2} \mathrm{Cu}_{2} \mathrm{O}_{5}$, six oxygen atoms coordinate to a $\mathrm{Cu}^{2+}$ ion to form an octahedron and these six oxygen atoms are highly distorted. That is, the two axial oxygen atoms are longer than the four equatorial ones. Therefore, $d_{x^{2}-y^{2}}$ orbitals in $\mathrm{Cu}$ are half-filled and $d_{z^{2}}$ orbitals are com-

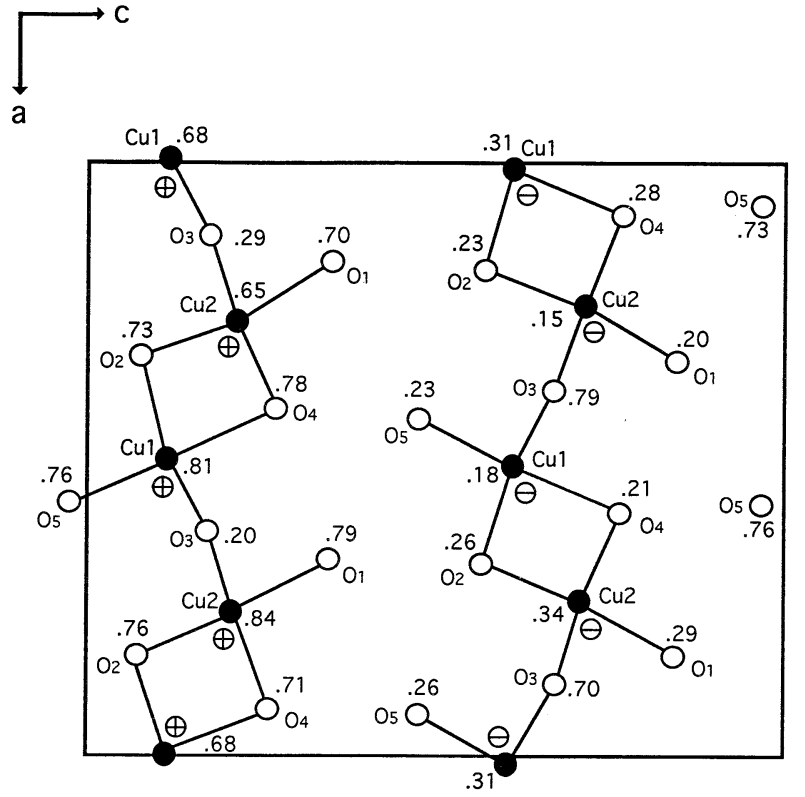

Fig. 5. Illustration of $\mathrm{Ho}_{2} \mathrm{Cu}_{2} \mathrm{O}_{5}$ structure in the $a c$ plane without Ho ions. Spin orientations of $\mathrm{Cu}^{2+}$ in the antiferromagnetic state are indicated by symbols $\oplus$ and $\Theta$.

pletely filled. The isolated spin in the $d_{x^{2}-y^{2}}$ orbital of every $\mathrm{Cu}$ ion in the $\mathrm{Cu}-\mathrm{O}$ chain ( $a$-axis) is strongly ordered ferromagnetically by the super-exchange with the combination of oxygen p orbitals and shows one-dimensional interaction characteristics along the $a$-axis. In addition to this, weak ferromagnetic interaction exists between the $a$-axis along the $b$-axis. ${ }^{9)}$ Along the $c$-axis, the isolated spin in $\mathrm{Cu}^{2+}$ weakly orders antiferromagnetically.

In the neutron diffraction refinement for $\mathrm{Sc}_{2} \mathrm{Cu}_{1.6} \mathrm{Co}_{0.4} \mathrm{O}_{5}$, three models have been postulated. The first one is that Co ions substitute only for $\mathrm{Cu}_{1}$ sites in Fig. 5. The second is that Co ions substitute only for $\mathrm{Cu}_{2}$ sites. The third is that doped Co ions equally substitute for both $\mathrm{Cu}_{1}$ and $\mathrm{Cu}_{2}$ sites. Although all three models can be refined to the same degree, the first two models gave negative individual temperature factors for the $\mathrm{Cu}$ and $\mathrm{Co}$ atoms. The third (disordered-Co) model gave realistic temperature factors for all atoms. Based on the neutron refinement results, we can conclude that the third model, where $\mathrm{Co}$ equally substitutes for both $\mathrm{Cu}_{1}$ and $\mathrm{Cu}_{2}$ sites, is most appropriate. The results of the refinement are listed in Table 1 and bond distances and bond angles are tabulated in Table 2. From the refinement results, the $\mathrm{Cu}_{1}-\mathrm{O}_{4}$ and $\mathrm{O}_{5}-\mathrm{Cu}_{1}$ angle in the $\mathrm{Cu}_{1}-\mathrm{O}_{4}-\mathrm{O}_{5}-\mathrm{Cu}_{1}$ ordering illustrated in Fig. 6 is calculated to be $130.4^{\circ}$ and $135.5^{\circ}$ for $\mathrm{Sc}_{2} \mathrm{Cu}_{2} \mathrm{O}_{5}$ and $\mathrm{Sc}_{2} \mathrm{Cu}_{1.6} \mathrm{Co}_{0.4} \mathrm{O}_{5}$, respectively. In the case that $\mathrm{Co}^{2+}$ partially substitutes for the $\mathrm{Cu}$ site in the $\mathrm{Sc}_{2} \mathrm{Cu}_{2} \mathrm{O}_{5}$ structure, the lattice parameter $c$ increases as shown in Fig. 1 (II). However, the distance between $\mathrm{O}_{4}$ and $\mathrm{O}_{5}$ was found to decrease from 0.294 to $0.285 \mathrm{~nm}$ by the neutron refinement. This means that the $\mathrm{Cu}-\mathrm{O}-$ $\mathrm{O}-\mathrm{Cu}$ ordering along the $c$-axis approaches a more 
Table 1. Crystallographic Parameters of $\mathrm{Sc}_{2} \mathrm{Cu}_{1.6} \mathrm{Co}_{0.4} \mathrm{O}_{5}$ from Neutron Powder Diffraction Data

\begin{tabular}{|c|c|c|c|c|c|c|}
\hline \multicolumn{7}{|c|}{ Space Group: Pna 2,} \\
\hline \multicolumn{7}{|c|}{ Unit Cell Parameters $(\mathrm{nm})$ : } \\
\hline \multicolumn{7}{|c|}{$b=0.32112(5)$} \\
\hline \multicolumn{7}{|c|}{$c=1.2069(2)$} \\
\hline \multicolumn{7}{|c|}{$z=4$} \\
\hline Atom & Site & $x$ & y & $z$ & $B\left(n m^{2}\right) \quad 0$ & Occupancy \\
\hline Sc1 & $4 a$ & $0.217(1)$ & $0.223(4$ & 0.0 & $.006(3)$ & 1.0 \\
\hline $\mathrm{Sc} 2$ & $4 a$ & $0.041(1)$ & $0.225(3$ & $0.3318(6)$ & $0.004(3)$ & 1.0 \\
\hline $\mathrm{Cu} 1 / \mathrm{Co} 2$ & $4 a$ & $0.992(3)$ & $0.666(8$ & $0.109(3)$ & $0.002(4)$ & $0.8 / 0.2$ \\
\hline $\mathrm{Cu} 2 / \mathrm{Co} 2$ & $4 a$ & $0.254(3)$ & 0.67217 & $0.219(3)$ & $0.009(4)$ & $0.8 / 0.2$ \\
\hline 01 & $4 a$ & $0.170(2)$ & $0.727(2$ & $0.357(2)$ & $0.002(.2)$ & 1.0 \\
\hline 02 & $4 a$ & $0.327(2)$ & $0.720(8$ & $0.068(3)$ & $0.002(1)$ & 1.0 \\
\hline 03 & $4 a$ & $0.124(5)$ & $0.282(7$ & $0.172(3)$ & $0.002(1)$ & 1.0 \\
\hline 04 & $4 a$ & $0.437(3)$ & $0.769(9$ & $0.268(3)$ & $0.002(1)$ & 1.0 \\
\hline 05 & $4 a$ & $0.415(3)$ & $0.253(8$ & $0.459(2)$ & $0.002(1)$ & 1.0 \\
\hline \multicolumn{3}{|c|}{ Nuclear RN } & \multicolumn{2}{|c|}{0.0490} & & \\
\hline \multicolumn{3}{|c|}{ Profile $R_{p}$} & \multicolumn{2}{|c|}{0.0379} & & \\
\hline \multicolumn{3}{|c|}{ Weighted Profile RwP } & \multicolumn{2}{|c|}{0.0504} & & \\
\hline \multicolumn{3}{|c|}{ Expected RE } & \multicolumn{2}{|c|}{0.0294} & & \\
\hline \multirow{2}{*}{\multicolumn{3}{|c|}{$\begin{array}{l}\text { No. of Profile Points } N \\
\text { No. of Parameters Refined }\end{array}$}} & \multicolumn{2}{|c|}{961} & & \\
\hline & & & & 47 & & \\
\hline \multicolumn{5}{|c|}{ No. of Independent Reflections 351} & & \\
\hline \multicolumn{3}{|c|}{$2 \theta$ Range $\left({ }^{\circ}\right)$} & & $2-108$ & & \\
\hline
\end{tabular}

Table 2. Bond Distances (nm) and Bond Angles $\left(^{\circ}\right)$ in $\mathrm{Sc}_{2} \mathrm{Cu}_{1.6} \mathrm{Co}_{0.4} \mathrm{O}_{5}$

\begin{tabular}{|c|c|c|c|}
\hline Sc1-01 & $0.209(3)$ & $5 c 2-01$ & $0.212(3)$ \\
\hline Sc1-02 & $0.213(3)$ & $\mathrm{Sc} 2-03$ & $0.212(4)$ \\
\hline $\mathrm{Sc} 1-\mathrm{O}_{2}{ }^{*}$ & $0.214(3)$ & $\mathrm{Sc} 2-04$ & $0.210(3)$ \\
\hline Sc1-03 & $0.230(4)$ & $\mathrm{Sc} 2-04^{\prime}$ & $0.207(3)$ \\
\hline Sc1-05 & $0.224(3)$ & $S c 2-05$ & $0.202(3)$ \\
\hline $\mathrm{Sc} 1-05^{\prime}$ & $0.210(3)$ & Mean & 0.209 \\
\hline Mean & 0.217 & & \\
\hline $\mathrm{Cu} 1 / \mathrm{Co} 1-02$ & $0.183(4)$ & $\mathrm{Cu} 2 / \mathrm{Co} 2-01$ & $0.189(4)$ \\
\hline $\mathrm{Cu} / \mathrm{Co1}-03$ & $0.199(5)$ & $\mathrm{Cu} 2 / \mathrm{Co} 2-02$ & $0.198(4)$ \\
\hline $\mathrm{Cu} 1 / \mathrm{Co} 1-04$ & $0.201(5)$ & $\mathrm{Cu} 2 / \mathrm{Co} 2-03$ & $0.193(5)$ \\
\hline $\mathrm{Cu} 1 / \mathrm{Co} 1-05$ & $0.207(4)$ & $\mathrm{Cu} 2 / \mathrm{Co} 2-04$ & $0.202(4)$ \\
\hline \multirow[t]{3}{*}{ Mean } & 0.198 & Mean & 0.196 \\
\hline & $\mathrm{Cu} 1 / \mathrm{Co} 1-\mathrm{Cu} 2 / \mathrm{Co} 2$ & $0.303(4)$ & \\
\hline & $\mathrm{Cu} 1 / \mathrm{Co} 1-\mathrm{Cu} 2 / \mathrm{Co} 2$ & $0.286(4)$ & \\
\hline O2-Cu1/Co1-O3 & $151(2)$ & $\mathrm{O} 1-\mathrm{Cu} 2 / \mathrm{Co} 2-02$ & $169(2)$ \\
\hline O2-Cu1/Co1-04 & $88(2)$ & $\mathrm{O} 1-\mathrm{Cu} 2 / \mathrm{Co} 2-03$ & $90(2)$ \\
\hline 02-Cu1/Co1-05 & $100(2)$ & 01-Cu2/Co2-04 & $99(2)$ \\
\hline $\mathrm{O} 3-\mathrm{Cu} 1 / \mathrm{Co} 1-\mathrm{O} 4$ & $84(2)$ & $\mathrm{O} 2-\mathrm{Cu} 2 / \mathrm{Co} 2-\mathrm{O} 3$ & $93(2)$ \\
\hline 03-Cu1/Co1-05 & $96(2)$ & $02-\mathrm{Cu} 2 / \mathrm{Co} 2-\mathrm{O} 4$ & $84(2)$ \\
\hline 04-Cu1/Co1-05 & $162(2)$ & 03-Cu2/Co2-O4 & $148(2)$ \\
\hline
\end{tabular}

linear configuration and that distance between oxygen atoms $\mathrm{O}_{4}$ and $\mathrm{O}_{5}$ decreases due to the Co doping. As a result, the overlap between two p orbitals of the $\mathrm{O}$ atoms in the $\mathrm{Cu}-\mathrm{O}-\mathrm{O}-\mathrm{Cu}$ arrangement increases as shown in Fig. 6.

Another $\mathrm{Cu}-\mathrm{O}-\mathrm{O}-\mathrm{Cu}$ arrangement also appears in $\mathrm{Cu}_{2}-\mathrm{O}_{1}-\mathrm{O}_{2}-\mathrm{Cu}_{2}$ (Fig. 5). However, in this case, the distance between the two oxygen atoms for $\mathrm{Sc}_{2} \mathrm{Cu}_{1.6} \mathrm{Co}_{0.4} \mathrm{O}_{5}$ is $0.302 \mathrm{~nm}$, which is $0.008 \mathrm{~nm}$ longer than that for $\mathrm{Sc}_{2} \mathrm{Cu}_{2} \mathrm{O}_{5}$. In addition, the direction of the $\mathrm{Cu}_{1}$ to $\mathrm{O}_{4}$ and $\mathrm{Cu}_{1}$ to $\mathrm{O}_{5}$ vector is in a cross direction, while that of $\mathrm{Cu}_{2}$ to $\mathrm{O}_{1}$ and $\mathrm{Cu}_{2}$ to $\mathrm{O}_{2}$ one is rather a parallel one. Therefore, the spin-spin inter-

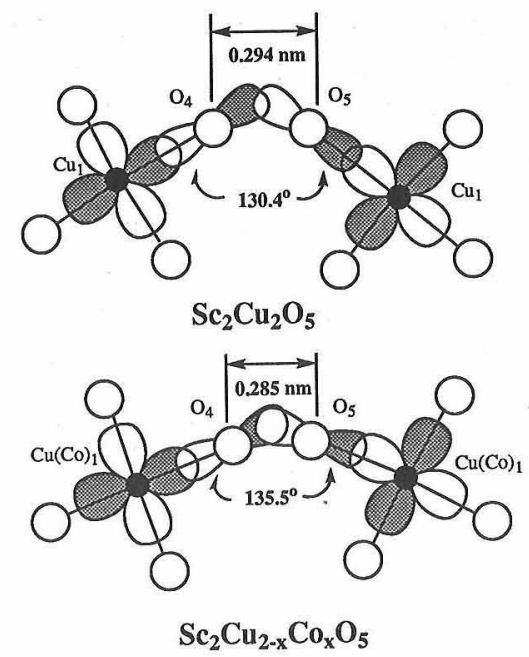

Fig. 6. Schematic representation of the overlap between $\mathrm{p}$ orbitals in two oxygen atoms for the $\mathrm{Cu}_{1}-\mathrm{O}_{4}-\mathrm{O}_{5}-\mathrm{Cu}_{1}$ arrangement.

action between the p orbitals of two oxygen atoms is expected to occur mainly in the $\mathrm{Cu}_{1}-\mathrm{O}_{4}-\mathrm{O}_{5}-\mathrm{Cu}_{1}$ arrangement. From the phenomena mentioned above, the superexchange interaction through the $\mathrm{Cu}_{1}-\mathrm{O}_{4}-$ $\mathrm{O}_{5}-\mathrm{Cu}_{1}$ arrangement becomes stronger as illustrated in Fig. 6 and therefore the antiferromagnetic ordering sets in at a higher temperature than that of pure $\mathrm{Sc}_{2} \mathrm{Cu}_{2} \mathrm{O}_{5}$ as indicated in Fig. 4.

The plots of $\chi_{m} T$ vs. $T$ for $\mathrm{Sc}_{2} \mathrm{Cu}_{2} \mathrm{O}_{5}$ and $\mathrm{Sc}_{2} \mathrm{Cu}_{1.6} \mathrm{Co}_{0.4} \mathrm{O}_{5}$ are shown in Fig. 7. In the case of $\mathrm{Sc}_{2} \mathrm{Cu}_{2} \mathrm{O}_{5}, \chi_{m} T$ increased with decreasing temperature. This behavior indicates that the $\mathrm{Sc}_{2} \mathrm{Cu}_{2} \mathrm{O}_{5}$ compound possesses ferromagnetic exchange coupling between $\left.\mathrm{Cu}^{2+}{ }^{2}{ }^{6}\right) \mathrm{Sc}_{2} \mathrm{Cu}_{1.6} \mathrm{Co}_{0.4} \mathrm{O}_{5}$, in contrast, showed no such maximum peak. The $\chi_{m} T$ decreased with decreasing temperature. The difference in the behavior of $\chi_{m} T$ vs. $T$ between $\mathrm{Sc}_{2} \mathrm{Cu}_{2} \mathrm{O}_{5}$ and $\mathrm{Sc}_{2} \mathrm{Cu}_{1.6} \mathrm{Co}_{0.4} \mathrm{O}_{5}$ explicitly reveals that the ferromagnetic interaction in $\mathrm{Sc}_{2} \mathrm{Cu}_{2} \mathrm{O}_{5}$ is destroyed by the $\mathrm{Co}$ doping in $\mathrm{Sc}_{2} \mathrm{Cu}_{2} \mathrm{O}_{5}$. The broad maximum peak at $50 \mathrm{~K}$ for $\mathrm{Sc}_{2} \mathrm{Cu}_{2} \mathrm{O}_{5}$ is close to the onset temperature of antiferromagnetic interaction.

We can also calculate the Curie constant $(C)$ from

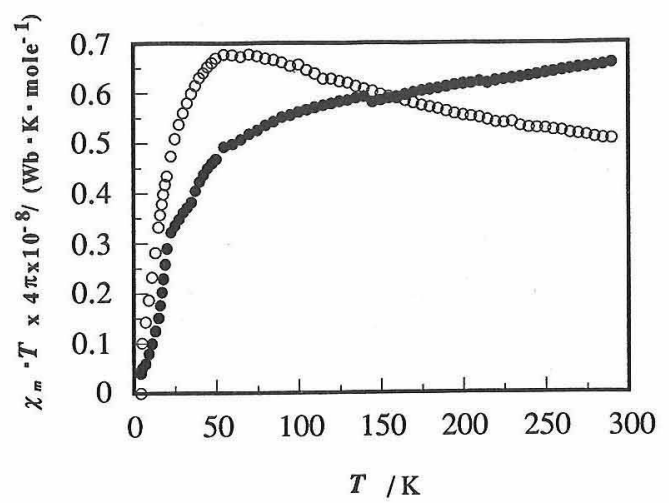

Fig. 7. The $\chi_{m} T-T$ relationships for $\mathrm{Sc}_{2} \mathrm{Cu}_{2} \mathrm{O}_{5}(\mathrm{O})$ and $\mathrm{Sc}_{2} \mathrm{Cu}_{1.6}$ $\mathrm{Co}_{0.4} \mathrm{O}_{5}(\mathrm{O})$. 
the slope of the $1 / \chi_{m}-T$ line in Fig. 3 as well as obtain the effective magnetic moment from the Curie constant. The slopes for $\mathrm{Sc}_{2} \mathrm{Cu}_{2} \mathrm{O}_{5}$ and $\mathrm{Sc}_{2} \mathrm{Cu}_{1.6} \mathrm{Co}_{0.4} \mathrm{O}_{5}$ are $2.39 \quad(C=0.418)$ and 1.24 $(C=0.805)$, respectively. The effective magnetic moments are calculated as 1.83 and 2.54 B.M., respectively. The effective magnetic moment and $C$ are tabulated in Table 3 for samples with $x=0.2$ and 0.6. Both $\mu_{\text {eff }}$ and $C$ monotonically increase with the amount of Co substitution. Since the $\mu_{\text {eff }}$ value for $\mathrm{Sc}_{2} \mathrm{Cu}_{1.6} \mathrm{Co}_{0.4} \mathrm{O}_{5}$, where one fifth of the $\mathrm{Cu}$ sites are replaced by Co, is 2.54 B.M., and the Co ions in the solid solution are determined to be in the divalent state from the oxygen content analysis, it is easy to deduce that the doped $\mathrm{Co}^{2+}$ ions are in a high spin state.

Moreover, the paramagnetic Curie temperature $\left(\theta_{\mathrm{p}}\right)$ obtained from Fig. 3 deviates toward negative values with the $\mathrm{Co}^{2+}$ doping. Since $\mathrm{Co}^{2+}$ is in a high spin state, both $d_{x^{2}-y^{2}}$ and $d_{z^{2}}$ are half-filled. Therefore, the doping of a high-spin $\mathrm{Co}^{2+}$ ion into a $\mathrm{Cu}^{2+}$ site hardly influences the superexchange interaction of half-filled $d_{x^{2}-y^{2}}$ in $\mathrm{Cu}^{2+}$ and $\mathrm{p}$ orbitals in $\mathrm{O}^{2-}$ between the $\mathrm{Cu}^{2+}$ ions along the $a$-axis. The Co doping is unrelated to the one-dimensional spin-spin interaction characteristics. In contrast, the weaker ferromagnetic interaction along the $b$-axis is between the half-filled $d_{x^{2}-y^{2}}$ and completely filled $d_{z^{2}}$ orbitals in $\mathrm{Cu}^{2+}$ of adjacent chains. In the case that $\mathrm{Cu}^{2+}$ ions are partially substituted for $\mathrm{Co}^{2+}$ ions, the interaction between $\mathrm{Cu}^{2+}$ and $\mathrm{Co}^{2+}$ is between the halffilled $d_{x^{2}-y^{2}}$ orbital of $\mathrm{Cu}^{2+}$ and the half-filled $d_{z^{2}}$ orbital of $\mathrm{Co}^{2+}$. The doping of $\mathrm{Co}^{2+}$ into the $\mathrm{Cu}^{2+}$ site reduces the ferromagnetic interaction along the $b$ axis. This is the reason for the deviation of $\theta_{\mathrm{p}}$ toward the negative direction.

In conclusion, $\mathrm{Co}^{2+}$ ions can substitute for both $\mathrm{Cu}_{1}$ and $\mathrm{Cu}_{2}$ sites of $\mathrm{Sc}_{2} \mathrm{Cu}_{2} \mathrm{O}_{5}$ equally and can form a solid solution with $x$ up to 0.4 in $\mathrm{Sc}_{2} \mathrm{Cu}_{2-x} \mathrm{Co}_{x} \mathrm{O}_{5}$. This substitution causes the enhancement of the overlap between two oxygen orbitals in the $\mathrm{Cu}-\mathrm{O}-\mathrm{O}-\mathrm{Cu}$ arrangement along the $c$-axis to strengthen the antiferromagnetic coupling and leads to the increase of the Néel temperature. The weaker ferromagnetic

Table 3. $\mu_{\text {eff }}$ and Curie Constant $(C)$ for $\mathrm{Sc}_{2} \mathrm{Cu}_{2-x} \mathrm{Co}_{x} \mathrm{O}_{5}$

\begin{tabular}{ccl}
\hline $\mathrm{X}$ & $\mu_{\text {eff }} / \mathrm{B} . \mathrm{M}$. & $\mathrm{C}$ \\
\hline 0 & 1.83 & 0.418 \\
0.2 & 2.41 & 0.724 \\
0.4 & 2.54 & 0.805 \\
0.6 & 3.21 & 1.29 \\
\hline
\end{tabular}

properties along the $b$-axis are partially destroyed by the doping and this results in a negative shift of the paramagnetic Curie temperature. In contrast, the doping does not affect the stronger ferromagnetic superexchange which gives rise to the one-dimensional magnetic behavior along the $a$-axis.

Acknowledgements The authors wish to express their thanks to Dr. K. Yoshimura and Mr. H. Kagayama, Department of Chemistry, Kyoto University for the torsion magnetic balance measurements. The authors also thank Dr. R. Troć at Polish Academy of Sciences for his many helpful discussions. The present work was partially supported by Grants-in-Aid for Scientific Research on Priority Areas, New Functional Materials-Design, Preparation and Control, Nos. 02205080, 03205082, and 04205091 from the Ministry of Education, Science and Culture, Japan.

\section{References}

1) H.-R. Freund and Hk. Müller-Buschbaum, Z. Naturforsch., 32b, 609-11 (1977).

2) H.-R. Freund and Hk. Müller-Buschbaum, Z. Naturforsch., 32b, 1123-24 (1977).

3) N. Kimizuka, E. Takayama, S. Horiuchi, A. Yamamoto and T. Fujita, J. Solid State Chem., 42, 322-24 (1982).

4) R. Troć, J. Klamut, Z. Bukowski, R. Horyń and J. StepieńDamm, Physica B, 154, 189-96 (1989).

5) R. Troć, Z. Bukowski, R. Horyń and J. Klamut, Phys. Lett. A, 125, 222-24 (1987).

6) B. L. Ramakrishna, E. W. Ong and Z. Iqbal, Solid State Commun., 68, 775-79 (1988).

7) Z. A. Kazei, N. P. Kolmakova, R. Z. Levitin, B. V. Mill, V. V. Moshchalkov, V. N. Orlov, V. V. Snegirev and Ja. Zoubkova, J. Magn. Magne. Mat., 86, 124-34 (1990).

8) J. L. Paillaud, P. Legoll and M. Drillon, J. Magn. Magne. Mat., 96, 41-46 (1991).

9) J. Aride, S. Flandrois, M. Taibi, A. Boukhari, M. Drillon and J. L. Soubeyroux, Solid State Commun., 72, 459-63 (1989).

10) J. Janicki and R. Troć, J. Phys. Cond. Mat., 4, 6267-74 (1992).

11) K. Sreedhar and P. Ganguly, Inorg. Chem., 27, 2261-69 (1988).

12) J. H. Brewer, E. J. Ansaldo, J. F. Carolan, A. C. D. Chaklader, W. N. Hardy, D. R. Harshman, M. E. Hayden, M. Ishikawa, N. Kaplan, R. Keitel, J. Kempton, R. F. Kiefl, W. J. Kossler, S. R. Kreitzman, A. Kulpa, Y. Kuno, G. M. Luke, H. Miyatake, K. Nagamine, Y. Nakazawa, N. Nishida, K. Nishiyama, S. Ohkuma, T. M. Riseman, G. Roehmer, P. Schleger, D. Shimada, C. E. Stronach, T. Takabatake, Y. J. Uemura, Y. Watanabe, D. Ll. Williams, T. Yamazaki and B. Yang, Phys. Rev. Lett., 60, 1073-76 (1988).

13) N. V. Porotnikov, K. I. Petrov, B. U. Asanov and I. I. Olikov, Russ. J. Inorg. Chem., 29, 1271-74 (1984).

14) A. Murasik, P. Fischer, R. Troć and Z. Bukowski, J. Magn. Magne. Mat., 127, 365-72 (1993).

15) R. D. Shannon, Acta Cryst., A32, 751-67 (1976).

16) J. N. Reimers, J. E. Greedan and M. Sato, J. Solid State Chem., 72, 390-94 (1988).

17) V. F. Sears, "Methods of Experimental Physics", Vol. 23a, Ed. by K. Skold and D. L. Price, Academic Press (1986) pp. $521-50$. 